\title{
Technique, power, transformation: views from Brazilian anthropology
}

\author{
Fabio Mura' \\ Carlos Emanuel Sautchuk ${ }^{2}$ \\ - Universidade Federal da Paraíba, Laboratório de Estudos em Processos Técnicos, \\ Departamento de Ciências Sociais, João Pessoa/PB, Brasil \\ 2 Universidade de Brasília, Laboratório de Antropologia da Ciência e da Técnica, \\ Departamento de Antropologia, Brasília/DF, Brasil
}

\begin{abstract}
The article presents contemporary approaches to the anthropology of technique, its theoretical-methodological specificities and the form in which it is expressed in Brazil today, exemplified through the set of ethnographies making up this dossier. Exploring different types of transformations, these articles raise questions concerning the relationship between technique and power, involving environments and territories, plants and animals, objects and skills. In seeking to overcome the limitations of the nature/culture dichotomy and its derivatives, technique-based approaches have turned to ethnographically grounded solutions that move beyond discourse and avoid the collapse into other ethnocentrisms, expressed in a total symmetrisation or in the mere projection of human properties to non-humans.
\end{abstract}

Keywords: Anthropology, technique, Brazil, transformation, power. 


\section{Técnica, poder, transformação: visões da antropologia brasileira}

\section{Resumo}

Este texto apresenta as perspectivas contemporâneas da antropologia da técnica, suas especificidades teóricometodológicas e a forma como ela se expressa no Brasil atualmente, através do conjunto de etnografias que compõem este dossiê. Abordando diferentes tipos de transformações, estes artigos evocam questões sobre a relação entre técnica e poder, tratando sobre ambientes e territórios, plantas e animais, objetos e habilidades. Defende-se que, ao tratar de superar as limitações da dicotomia natureza e cultura e seus derivados, as abordagens da técnica buscam soluções etnograficamente fundamentadas, que vão além do discurso e que evitam recair em outros etnocentrismos, expressos numa simetrização total ou na mera projeção de propriedades humanas aos não humanos.

Palavras-chave: Antropologia, técnica, Brasil, transformação, poder. 


\title{
Technique, power, transformation: views from Brazilian anthropology
}

\author{
Carlos Emanuel Sautchuk
}

Fabio Mura

The idea that technical transformations are a feature of modernity, or even an effect of globalization, is undeniably commonplace, just as we can frequently encounter reflections on the political impacts and power relations implied in these phenomena. Some endeavours within anthropology have sought to frame this kind of problem in other terms, mobilizing the ideas of transformation, technique and power, not only as objects of study but as analytic categories and as guidelines for ethnographic approximation. This has led, including in Brazil, to a series of approaches founded on ethnography and has contributed new perspectives on themes that include relations with animals, plants, objects, skills, environments and territories, stimulating a debate on the potential meanings of these terms through a vision of processes.

\section{Technique: the idea of technology and the anthropological approach}

Whenever anthropology manipulates or interrogates wide-ranging notions that comprise central categories in western thought - such as economy, religion or individual - it is essential that some process of critical reflection is developed, usually based on an ethnographically informed perspective. The same applies, naturally enough, to the notions of technique or technology. It is important, then, to begin with a panoramic view of how these terms have been used in anthropology, including their limits and possibilities.

At one level, their use can be traced back to the initial phases of the discipline, whether in relation to magic (Malinowski, 1984), museological interest (Hicks, 2010), or even proposals concerned with the relation between culture and environment (Steward, 1955; White, 1949; Guille-Escuret, 1989). However, it can be said that the positing of technique or technology as a problem or a form of approach, such as it appears in the contemporary anthropological setting, became configured and deepened over the last two decades of the twentieth century through the interconnections of a set of researchers with different influences and interests - from huntergatherers to studies of science and technology, passing through economic anthropology and archaeology. A diverse spectrum of bibliographic production reveals the emergence and evolution to the present of an academic field with themes, concepts and debates that transcend national borders and styles. Over his period we can note the emergence of specialized journals (like Techniques \& Culture and also Journal of Material Culture), as well as the publication of books (Latour, 1996; Ingold, 1980; Lemonnier, 2012; Coupaye, 2013) and collections of individual articles that present ethnographic material and contain conceptual, analytic and methodological propositions focused on technique (Ingold, 2000; Sigaut, 2012; Hornborg, 2017). This includes the republishing (Haudricourt, 1987; 2010) and translation (Mauss, 2006a; Leroi-Gourhan, 1993; Schlanger, forthcoming) of authors considered to be important references. There are also collations and comparisons (Coupaye \& Douny, 2009; Bray, 2007), collective works (Latour \& Lemonnier, 1994; Lemonnier, 1993; Schiffer, 2001), texts on the state of the art and/or theoretical-methodological positionings (Pfaffenberger, 1992; Lemonnier, 1992; Ingold, 1997; Akrich, 1989; Buob, Chevallier \& Gosselain, 2019), as well as entries in specialized dictionaries (Sigaut, 1994; Lemonnier, 1991, 2011; Cresswell, 1991; Bril, 1991). 
A striking feature of this movement are the reservations concerning the various meanings of what Pfaffenberger (1992) called the "Standard View of technology": necessity is the mother of invention, the meaning of an artefact is a matter of surface style, and development is a cumulative and unilinear progression. Generally speaking, these everyday meanings of technology in western modernity have led anthropologists to either reject the term completely (Pfaffenberger, 1988, 1992; Ingold, 1997, 2000: 321) or try to redefine it (Lemonnier, 1992; Hornborg, 2014) for their own use. One point that surfaces frequently in these critiques is the need for anthropology to avoid setting out from the idea of technology as an autonomous and pre-existent system available to ethnographic discovery (Ingold, 1997: 132). Such a premise implies taking technology to be exterior to society, thus enabling a determinist attitude, as well as its relativist counterpart, inevitably activating dichotomies like nature/culture, material/ideal and subject/object. It was precisely this posture that allowed anthropology to ignore the theme - since it was presumed to exist outside the domains of culture - or to adopt an approach devoid of appropriate concepts and methods, purely descriptive and excessively focused on inventories or formalist descriptions, isolating objects from their real-world setting (Hicks, 2010).

On the other hand, the idea of technology as a scientific-industrial phenomenon can lead anthropologists to separate the study of so-called modern and traditional technologies into different areas or to apply different methods in their exploration, an attitude that has been rejected (Schiffer, 2001; Mauss, 2006a). Indeed, the ethnocentric potential of the term is embedded in this distinction (Ingold, 1997; Pfaffemberger, 1992), which mobilizes the idea of a sophisticated science-based technology (hence the suffix logos) in opposition to a simple and empirical kind. The same applies to the supposition that a set of relations exists between materials and artefacts (so-called technology) that differs fundamentally from other sets of relations - social, symbolic or environmental, for example. Much of the problem ends up residing in how to avoid the 'fatal dichotomy' between technique and society, which figures as a central concern of one of the influential collections in this field, edited by Latour and Lemonnier (1994: 13).

Despite these critiques, it is important to remember that the meanings and uses of technique, technology and correlated terms in anthropology vary significantly, a fact made clear in the articles featured in the present dossier. In the Francophone environment, for example, technology may signify the study or reflection on technique (Sigaut, 1994: 422; Latour, 2010: 21). This has implications for anthropology, as Coupaye (2009) indicated, which is connected to the tradition inspired by Mauss's reflections on the topic (Mauss, 2006a). We should begin by recalling that the translation of Latin authors, especially Francophones (see, for example, Latour, Foucault, Ellul, Daumas, Mauss, Lemonnier), generates some confusion since technologie is very often rendered as technology. More than a few French authors have taken issue with use of the term technology, considering it mistaken or abusive (Séris, 1994: 3-6; Sigaut, 1994: 442; Latour, 1994).

It is not our intention here to defend the notion of technique against that of technology, but to point out the risky and uncertain implications (Marx, 1997) of the latter, which, in fact, emerged very recently in western history. ${ }^{1}$ Precisely for this reason, it is worth anthropologists taking heed of the warning of French philosopher Jean-Pierre Séris (1994: 1): “technology should not hide techniques from us.” Indeed, while recognizing its limited use in English, here we adopt the term technique, rather than technology, precisely to demarcate a distance in relation to the premises contained in the latter and to allow more inclusive perspectives on the topic. There are important precedents in Anglophone anthropology for preferring the term techniques, among them Ingold (2000: 314-7), whom we follow to a large extent here.

\footnotetext{
Understanding the presence and effects of the notion of technology in western modernity, and the marked increase in its use over the course of the twentieth century, has been the focus of a number of recent studies. Among them we can note the historiographic approaches of Marx (1997) and Schatzberg (2018), who also explore appropriations of the notion of 'technology' in the social sciences. The consequences of these works have had repercussions too in anthropology (e.g. Coupaye \& Pitrou, 2018).
} 
But given all these reservations and difficulties, why insist on this theme at the current juncture? One of the first points is that technique should not be considered merely as an object of study, as a phenomenon in and of itself. Neither should it be taken simply as the action of a subject on an object, or the human being on the environment. More productively, it can be thought of as (diverse) forms of relation or mediation. This is why asking about technique signifies addressing some of the central questions and dilemmas of the contemporary scenario, such as the distinction between nature and culture, or the debate on the epistemic scope and possibilities of anthropos itself. In this regard, it is necessary to point out the specificity of the technique-based approach compared to other contemporary movements that seek to extend anthropology's attention to objects or non-humans in general.

The technique-based approach retains specificities vis-à-vis the so-called agentive turn or material cultural turn (Hicks, 2010; Chua \& Salmond, 2012), which broaden the reach of anthropology's theoretical apparatus to encompass new beings and things (Apparadurai, 1986; Miller, 2005; Gell, 1998). True, there are many proximities and complementarities, but while sharing the same aim to amplify anthropology's scope, technique-based approaches adopt a different epistemological strategy to these other movements: less the 'amplification' in the range of the theoretical-conceptual apparatuses used by the social sciences, and more the 'introjection' of new empirical sensibilities and research questions into anthropology. This is the case, for example, of actor-network theory and its initial approach to everyday objects and innovations (Latour, 1992; Akrich, 1992), French cultural technology and its attention to the operational dimension, objects and gestures (Lemonnier, 1993; Sigaut, 1994) and Ingold $(1997,2000,2011)$ and his perspective of life, the environment and skill. The notion of technique is affirmed by these authors essentially as a form of perceiving and dealing with relations and processes invisible to the usual concepts and methods of social or cultural anthropology - the proposal of notions like translation, operational sequence and skill characterize well this objective of renewing ethnographic potentials.

The contemporary relevance of this introjection of new themes, concepts and empirical sensibilities becomes evident in the comments to the book by Lemonnier (2012), which updates a number of convergences between different approaches to technique. Despite the disagreements, Latour (2014) recognizes that the more localized and detailed approach promoted by Lemonnier (1993) aligns with the contemporary political urgency of focusing on the singularities of different 'material infrastructures.' Ingold (2014: 520), for his part, though more critical, displays a degree of convergence with Lemonnier's empirical approach, arguing the need for anthropology to go 'back to basics' - that is, resume its empirical contact with the dynamic of things and movements.

These specificities provide a basis for us to comprehend how the attention to technique has been assuming broader contours within anthropology, far from remaining bound to a narrow instrumentalism. After a lengthy period of ostracism, therefore, it seems to be recovering a more relevant position, including in anthropological studies that aim to develop more general reflections, especially those concerned with rethinking the status of the human and its relation to the environment (Descola, 2013; Ingold, 2000). At the same time, renewed uses of the term are also being proposed by authors seeking to investigate life processes (Pitrou, 2015; Coupaye \& Pitrou, 2018). Similarly, technique or technology have been mobilized - sometimes in a divergent or even contrasting way - by authors concerned with the Anthropocene (or Technocene) and the political and cosmological (or cosmopolitical) reasons and consequences of the disparity in the modes of existence impelled by present-day capitalism on a planetary scale (Latour, 2013; Hornborg, 2017).

One of the motives for this resurgent interest in technique within anthropology seems to be that it provides a way to move on from the theoretical critique of the nature/culture distinction through forms of ethnographic approach that explore the relations between humans, environments, objects and animals. This helps explain why authors who developed their approaches via epistemological positions that expressly avoided mobilizing, even critically, the dilemmas of nature/culture, subject/object and discourse/practice have attracted much interest 
today, figuring as central references in studies of technique. Such seems to be the case of Leroi-Gourhan (1993), whose ideas have been disseminated by Ingold (1999) in the Anglophone environment, since, by thinking a new interface between biology and anthropology through technique, the former's work converges with the latter's critique of the oppositions between humanity/animality and subject/object (Mura, 2011). We can also mention Haudricourt (1969), who Descola (2013: 105-6) cites in order to explore his seminal ideas on the homology between social relations and relations with nature, and whose work has also been revisited in order to propose a theory of action (Ferret, 2014). We should not forget either the revisiting of Mauss's thought on technique (Mauss, 2006a), which is markedly relational. Also included in this scenario is the influence exerted by the thought of the philosopher of technique and individuation, Gilbert Simondon (1989; Ingold, 2013; Sautchuk, 2019, 2015). Its interest in anthropology would appear to reside precisely in the empirical approximation to phenomena like technique and individuation (physical, biological, psychological and collective) without resorting to the theoretical paradoxes that arise from the notions of nature and culture, or matter and form. Simondon's (2016) treatment of the technical object offers viable alternatives to perceiving the configuration of effective combinations between the living and the non-living that are rendered more or less imperceptible through the notion of artefact (Guchet, 2017). By recuperating the approaches of these authors, different notions have been revisited, such as technical trend (tendance technique), gesture, operational sequence and behaviour, concretization and individuation.

This overview allows us to highlight the fact that, for contemporary anthropology, the relevance of the proposals for exploring technique is strongly methodological in character. In other words, in the dialogue with these authors, the aim is to encounter solutions for dealing empirically with the dynamic of diverse processes that bring together humans, animals, objects, environments and so on. However, in the contemporary context of proposals that seek to overcome the limitations of dichotomies like nature/culture, subject/object, human/ animal or ideal/material in anthropology, technique-based approaches offer an ethnographically grounded solution that avoids the collapse into other ethnocentrisms, expressed in either a total symmetrisation or the mere projection of human properties to non-humans. In sum, the approximation to operations, fabrications and forms of action enables us to observe that power relations, which could be taken as exterior to technique (determining or being determined by it), are actually situated within its own dynamic.

\section{Technique and power: looking at operations}

Studies of power in the social sciences tend to concentrate on the economic, social and symbolic effects created by relational disymmetries, as well as the construction of hierarchical systems and the implementation of logics of domination and management of people and energy resources, as found in the works of classic authors like Karl Marx, Karl Polanyi, Eric Wolf, Claude Meillassoux, Max Weber, Norbert Elias, Michel Foucault, Louis Dumont, Leslie White and Pierre Bourdieu.

Frequently these studies make use of metaphors taken from physics to describe the mechanisms that define power and its effects on the life of humans and beyond. Elias (1978), for example, illustrating how social configurations are constructed, draws inspiration from game theory in order to define power as a differential system of forces, in the physical sense of the term, existing between two or more human subjects, which implies the formation of hierarchically ordered social relations. Foucault (1975), for his part, considered power relations to be a microphysics and a technology. Along these lines, he cites notions and ideas derived from particular techniques performed by humans, such as herding, in order to classify and differentiate the distinct modalities of managing and governing humans themselves (Foucault 1994). Use of the metaphor of the herder in the ancient world, Foucault claimed, originated mainly from the Middle East and was based on the experience of 
herding sheep and goats, where detailed and differentiated recognition and treatment of each animal subject was a fundamental aspect. Tutelary power itself came to be considered by the French author as an expression of this detailed form of caring for and conditioning human individuals too.

As can be noted, significant connections exist between Foucault's conceptualization of power and his concerns with techniques, beginning with the idea of techniques of the body, which implies thinking of all action as deriving from a specific tradition and form of transmission (Mauss, 2006b). The fact that for Mauss the principle of social action is not external but situated within the flow of life itself (Karsenti, 1998) is what allows us to glimpse a connection between such proposals as diverse as Leroi-Gourhan's technical gesture (1993) and Foucault's disciplinary power and techniques of the self. Canguilhem's (2008) thought contains the most explicit articulation of these two fields, when he emphasizes the normative character of processes, including the body, the technical dimension and the relation with the environment. The repercussions of this approach have been widely explored by the social sciences in specific fields - notably in medicalization processes - and surveying these works here in detail would be impossible. However, it is worth briefly pointing out how this articulation between technique and power can be explored via questions relating to life, action and intention.

We take two ethnographic examples. In a text on domestication processes, Carole Ferret (2014) relates that the Yakut describe mosquitos as 'little shepherds' and adds that this is not simply a metaphor. In effect, the active participation of the mosquitos allows horses to be attracted towards points of smoke where they can protect themselves from their bites. The mosquitos cannot be said to have the intention of contributing to the herding of the horses, but the effects of their actions are precisely the same. In this sense, and considering the process led by the Yakut, the mosquitos behave like little shepherds. On the use of analogies, a similarly interesting comparison is made by a prestigious Kaiowa shaman to explain to a non-indigenous interlocutor how a ñengáry functions - that is, a chant used to move vertically through distinct levels of the cosmos (Mura, 2019). The shaman compares it to an elevator that allows access to the various floors of a building. In this case, we might think that the elevator has a metaphoric value. What would happen, though, if this same shaman had to explain how an elevator works to a relative who had never seen one? He would probably use the ñengáry mechanism, which for the Kaiowa is something concrete, based on physical principles. This would lead to an inversion of the metaphoric relation, or more exactly, the perception that comprehending both phenomena require us to go beyond the use of metaphors.

In fact, these ethnographic examples allow us to conclude that, in general, conceiving of technical and physical relations and principles as metaphors is more the outcome of a preconceived division between a sociocultural dimension and another material dimension, rather than an attempt to distinguish between specific properties of forms of acting. Moving beyond the material/immaterial dichotomy, therefore, instead of mere metaphors we could more accurately speak of analogies, homologies and, in the specific case of herding, even variants of the same way of directing an action towards specific beings in order to govern or induce them into a particular form of action. ${ }^{2}$

Haudricourt (1969) presents an argument that is, to some extent, complementary to Foucault's. While the latter argues that we need to turn to the relation with animals to understand relations between humans, Haudricourt's argument points to the inverse. He compares different forms of domestication and agriculture, those from the Mediterranean region with others from the Far East and Melanesia. In the first case, what he defines as a 'positive direct action' takes place: that is, human activities in the breeding of animals and in agricultural work is characterized by a high degree of intervention and direct control over the behaviour of

\footnotetext{
2 In this sense, governing oneself implies a political attitude. We can speak of political technique in terms already posed by Plato, considering it a technique of use, that seeks to administrate and govern other techniques of production and acquisition (Cambiano, 1971; Mura, 2017). In turn, taking political behaviour as the search to achieve a particular objective within a framework of actions and relations characterized by a power differential, as already defined by Swartz, Turner and Tuden (1966) in the introduction to the classic Political Anthropology, suggests the need for a post-metaphoric and post-dichotomic approach to the relation between technique and politics.
} 
domesticated species. The other model is 'indirect negative action,' acting on the environment in order to interfere only with the conditions of the characteristic actions and processes of plants or animals. He then identifies a homology in the principles of action between each of these two models of cultivation or breeding and the different forms of government (what he calls relations with the other) characteristic of these two regions.

Reclaiming Haudricourt's formulations but with the aim of overcoming his schematicism, Ferret (2014) proposes using the notion of 'manipulation,' borrowed from semiotics. As well as speaking of a subject and its objective, therefore, it would also be possible to include the object of an action, thereby forming a trinomial. This would allow us to observe how, within specific processes and practices, subjects and objects condition each other, making it possible to apprehend the objective as something emergent from these actions. Setting out from Haudricourt, therefore, Ferret proposes extending the variety of modes and intensities of action to include others like: making the other do (intervention), preventing the other from doing (prevention), not preventing the other from doing (laissez-faire), not making the other do (non-intervention).

Ferret's proposal (2014) proves highly productive in terms of delineating an anthropology of action since, as the author herself states, it shifts the focus from 'why' to 'how,' making practices and processes central to the definition of relational models. Hence, it is possible to imagine that technical choices emerge from the actions themselves derived from each context. By focusing on processes and shifting away from intention, this type of approach points to one of the main interests of the approaches to technique, namely a vision internal to processes. True enough, it is notable that the gestures and rhythms in the development of an activity are linked to the consolidation of positions and power relations, which allow certain intentions to condition some processes more than others. ${ }^{3}$ In other words, this kind of approach is not incompatible with analyses of the structure of social action, likes those of Barth (1992), which takes intentions to be acts focused on producing sequences of events, which become conditioned in the process. Indeed, technical actions should always be considered within a set of relations in a specific socio-ecological-territorial context (Mura, 2011, 2019). On the other hand, it is worth noting that governance practices can be conceived as political techniques, generating a distribution of forces and the differential mobilization of materials and beings. If all these actions were always symmetric and equivalent, we would end up with stasis. Operational movements are precisely not the result of equivalences but of differentials of various types.

It should be noted that the aim here is not to instigate a debate on whether or not techniques or artefacts manifest political agency. Rather it is a question of avoiding any pre-differentiation of those relations we consider as techniques and others we consider as social or political in kind. It follows that we need to think of technical objects and living beings from a perspective that does not define them in advance, but also simultaneously does not fail to perceive their characteristic properties within a specific type of relation and interaction. This approximation between the technical and the living is an important aspect of the ideas of Canguilhem, which directly influenced not only Foucault, but Simondon too.

For Simondon (2016), it is only possible to comprehend technique through a vision of the processes of individuation (see Sautchuk, 2019). Consequently, if there is no absolute difference, there also exists no identity between the technical object and organisms - this relation and difference is precisely an empirical question and lies at the core of every technicity. Indeed, this is one of the main points of contact between his proposal and that of Leroi-Gourhan, who adopts this approach to technique to comprehend gesture and tool,

\footnotetext{
3 Here it is important to emphasize that although studies of power and social action consider intentionality in terms of the behaviour manifested by human beings, which predominate, it is not exclusive to them. This fact is related in particular to the capacity of every living organism to acquire, transmit and manage information, giving life to specific operational behaviours (Leroi-Gourhan, 1993). Intentionality, therefore, depending on the characteristics of the species and the environmental experiences of the specimens related to each other in a determined context, involving factors of differentiation of abilities, skills and social status, contributes to the formation of a dissymmetric interplay of power relations fed by the force, direction and intensity of the actions to which each human and non-human element will give life in this context. It is also important to emphasize that these elements in the context and process of individuation and transduction cannot be understood to constitute two separate categories, subjects and objects - that is, treated as substantives. Each element in this flux can be the subject of one action and the object of another action promoted by other elements (Mura, 2011).
} 
but also the bodily constitution and technical behaviour of diverse beings, including their spatial projections. This type of consideration by-passes the idea of an agency that could be distributed or projected, exploring instead different forms and types of action on relational configurations.

The relation between technique and power cannot be considered in terms of causality or determination, thinking about the control or effects of a given technique. We need to take into account the modes through which different beings and processes become implicated and their properties emerge in the flux of relations. This leads us precisely to argue that to inquire into technique is to speak about processes of transformation.

\section{Transformations: variants of technique in Brazilian anthropology}

In Brazil, the first associations with this forming of an interest in technique in contemporary anthropology emerged in research with indigenous peoples, such as those studies on the inclusion of new materials and the meaning of technical actions (Mura, 2000, 2011), as well as on the connection between objects and their uses and meanings (Silva, 2002). To this we can add the interest in the relationship between technical skills, personhood and environment based on the dynamic of fishing in Amazonia (Sautchuk, 2005, 2019, forthcoming). This initial scenario, after expanded, had already signalled an important trait, namely that the recourse to technique should be conceived as developing or connecting to other thematic fields.

Here, the interest in technique to some extent runs parallel to the emergence of a more general interest in the relation between humans and non-humans, which has configured around approaches linked to science and technology. It is precisely the studies of indigenous material culture, productive activities in the rural world, and relations with the environment that have been combining with explorations of the new biotechnologies, especially in the fields of medicine and healthcare, associated too with the emergence of an interest in the practice of scientists (Sautchuk, 2010). ${ }^{4}$ All of this assumes specific contours in the Brazilian context, considering two characteristics of the anthropology produced in the country. The first relates to the different gradations of alterity that mark the practice of anthropologists in Brazil (Peirano, 1991, 1999; Simião \& Feldman-Bianco, 2018), which always generates a range of political reverberations. The second is the relatively diverse and eclectic form in which different anthropological currents on technique have been convoked to interconnect with themes and perspectives already consolidated in the country. Indeed this is how we should understand the mobilization of an approach to technique among anthropologists in Brazil, which is presented here in three sections: one concerning the question of environments and territories, another on the human relationship with plants and animals, and a third on skills and objects.

The attention given by anthropologists working in Brazil to techniques highlights processes of change under way, whether due to an interest in the emergence or diffusion of new practices, or due to the way in which different phenomena - ranging from the environment to animals or humans - are transformed through certain technical processes. What follows is a representative sample of this movement, including anthropologists

4 Anthropologists dedicated to the study of technique have been constituting collective initiatives over recent years in Brazil. The Reunião de Antropologia da Ciência e da Tecnologia (ReACT: Meeting of the Anthropology of Science and Technology), held biannually, tends to include research along these lines, alongside other approaches like STS, multispecies studies and perspectives based around the ontological turn. The last three editions of the Reunião Brasileira de Antropologia (Brazilian Anthropology Association Meeting) have included a thematic group on the Anthropology of Technique, dynamized by the organizers of this dossier and authors contributing to it. The project Transformações técnicas em perspectivas locais (Technical transformations in local perspectives, funded by the Brazilian National Council for Scientific and Technological Development) has given impulse to collective research, which added other initiatives at a colloquium held in Brasilia, 2015, the results of which can be found in the first collection of texts on the theme to be published in the country (Sautchuk, 2017). Another important factor in the consolidation of technique as a theme was the seminar Ambientes, percepções e práticas (Ambients, perceptions and practices), organized one year before in Florianopolis and that also involves the participation of various authors of the present dossier. We can also cite the creation of research groups in different regions of the country, uniting anthropologists around the technology theme: the Laboratory of the Anthropology of Science and Technique (Laboratório de Antropologia da Ciência e da Técnica: LACT, University of Brasília), the Ambients, Perceptions and Practices Study Collective (Coletivo de Estudos em Ambientes, Percepções e Práticas: CANOA, Federal University of Santa Catarina) and the Technical Processes Study Laboratory (Laboratório de Estudos em Processos Técnicos: Téchnai, Federal University of Paraíba). 
from all over Brazil, presenting ethnographic research conducted in the five regions of the country. Set in the country's diverse biomes or metropolitan cities, here we present a varied panorama, characterized by urban and rural situations, referring to indigenous peoples or medical practices, historical perspectives and analyses of gestures, the introduction of computers and the utilization of industrial devices and materials in fishing techniques.

In the first section of this special number, on environments and territories, Fagundes presents us with a scenario in which the management of burns and wildfires in the savannahs of Central Brazil involves disparate perceptions, mobilized by agents of the state or quilombola communities. Based on the concept of normativity of Canguilhem (1991), the author shows how the technical transformations implemented in these spaces and environments through the work of the quilombola populations are focused on producing a "harmonious and rhythmed existence between fire and forms of life," producing a "territorialisation of milieus and rhythms." Through these practices, the quilombola communities rebalance the power relations arising from the state's application of fines and bans on burning.

As in the case of fire, the rhythmic dimension of technical relations is fundamental to comprehending how the Panará indigenous people of southern Amazonia undertake their hunting trips. As Bechelany shows, it is through this mode that they produce an ontogenesis of technical and social relations, including the act of walking in the forests and the forms of collaboration and perception. Inspired by Simondon (2005), the author takes individuals (humans and animals, hunter and prey) to be "unstable realizations where the problem is the maintenance of a unity, whose important characteristic is its functional autonomy, not its morphological unity."

Araújo, meanwhile, discusses mobility in space and relations in the mangrove environments in which Potiguara indigenous families develop their activities and domestic ecology in the Brazilian Northeast. Primarily making use of the concepts of technical trend, technical environment, technical fact and technical set of Leroi-Gourhan (1971), in this work the author shows how experiential trajectories, skills and acquired knowledge enable this indigenous population to design, through their domestic units, domains in which flows of materials of local and industrial origin are organized and mutually associated in the fabrication of objects and tools.

Concluding this section, Aderaldo's work reveals another aspect of the perception of space and the technical transformations that enable conflicting modes of constructing territories and urban territorialities. The author examines cartographic production as the generation of technical objects that involve political and symbolic factors, inspired by Akrich's work $(1989,1992)$ on the formation of sociotechnical systems and the description of technical objects. Thus, hegemonic maps, whose intentionality is focused on rendering invisible the everyday, the gender dimension and the manifestations of diverse social segments, are questioned by associations and activities that seek to contrast their power effects, producing as an alternative "critical maps" that allow people to "inhabit experiences."

In the next section, different processes of change in the human relationships with plants and animals are studied. Oliveira explores the situation of pluriethnic indigenous communities on the border between Brazil and Guiana through a technogenetic approach to the manioc-stem. The way in which these plants are transformed into food and, at the same time, activate certain indigenous relational modes is studied in detail through the methodological employment of the notion of operational sequence, taking it as a transect (Coupaye, 2017) capable of perceiving heterogenic aspects like vital flows, gestures and discourses.

Di Deus explores another plant central to the history of Amazonia, the rubber tree (Hevea brasiliensis). He focuses on the response of this tree to the technical gesture of extracting the latex, linking contemporary plantations in the state of São Paulo with the beginnings of the famous transportation of this tree to Asia at the end of the nineteenth century. By focusing on techniques through the percussive blow (Leroi-Gourhan, 1971) and the rhythm of human-plant interaction, paying special attention to strategic operations (Lemonnier, 1992: 21-24), his ethnographic and historical study sheds fresh light on the topic. He questions the simplistic 
narrative of the transportation of the seeds, highlighting the relevance of Amazonian knowledge and practices (Nugent, 2018), thus emphasizing the need to speak of technical systems in diaspora.

Deturche also adopts the notion of rhythm to explore changes in the relationship between technique and life dynamics in the intensification of production. His interest is in the mechanization of milk extraction in France, rediscussing the complexity of domestication through milking robots. If these machines transform the system of domestication itself, it is because their concretization implies both a level of indetermination (Simondon, 2016) and a redesigning of skills (Ingold, 2000). Exploring these questions, the author shows the reaction of cattle breeders to the intentions of the engineers. So, while the latter see robotization as a way to lessen the time spent with cows, for the former this relationship redefined through ludic and affective finalities. Consequently, abandoning the unilinear conception of domestication processes does not imply ignoring the power asymmetries and relations involved.

Also backed by the ideas of Simondon (2016) and Ingold (2000, 2011, 2013) on technique and perception, Devos, Barbosa and Vedana join in the same type of critique of a dichotomy between modern technologies and traditional techniques. They examine the adoption of new technical devices (such as mobile phones, walkie-talkies, webcams and social network pages) in the revival of mullet fishing in Florianopolis on the south coast of Brazil. They emphasize its articulation with the technicity of collective practices and knowledge systems of artisanal fishing in contexts that can be comprehended through the notion of distributed cognition (Hutchins, 2001).

The negotiation of a field of actions and power between humans and animals, as well as the rediscussion of the theme of domestication, appear in the research of two authors studying animal participation in support or therapy for humans. Von der Weid presents a detailed analysis of the apprenticeship of guide dogs as an animal assistive technology to facilitate the mobility of the visually impaired. She emphasizes the emergence of a human/dog team, based on a kind of anthropozootechnical agency. This sophisticated and crucial cooperation, especially in terms of mobility, depends on the formation of technical devices and dispositions, which she interprets through the dialogue with animal studies, such as the proposition of its umwelt (Uexkull, 2010) and the ludic dimension of gesture (Massumi, 2014).

Teixeira, for her part, focuses on zootherapy, approaching it as a technical skill. Thus, the role of animals in healing or care processes leads to thinking about the transformations that these cause in humans and animals. Proceeding with a detailed analysis of these interactions through the studies of Haudricourt (1969) and methodological developments relating to the anthropology of action proposed by Ferret (2014), Teixeira shows the correlated processes of human and animal learning, as well as the relations of force established at the heart of this therapy.

In the final section, it becomes clear that technique should not be understood in and of itself but as a mediation that, in this case, places skills and objects in relation and interaction. Sordi shows how in the environment of the Pampa, in the far south of Brazil, previously characterized as an open landscape, the introduction of fences transformed the modes of relation between humans and animals. Dialoguing with the concept of architecture of domestication (Anderson et al., 2017), the author demonstrates how the introduction of fences represents a balanced mode between direct positive and indirect negative technical actions, maintaining a dialectic of control and reciprocity between humans and animals.

Investing in the productive interface between archaeology and anthropology, Silva centres her attention on ceramic production among the Asurini people of the Xingu Indigenous Park in Central Brazil, employing the idea of technical choice (Lemonnier, 1993) to show how matter and energy are transformed through this activity and how symbolic and aesthetic meanings are produced. As a consequence, as the author asserts, "during all stages of the operational sequence, the notions of utility and beauty combine with the themes of Asurini sociality and cosmology.” 
The concept of technical choice is also discussed by Ferreira Filho. Focusing on the Pataxó, an indigenous people of the Brazilian coast (Bahia state), the author seeks to comprehend the introduction, selection and use of computers, smartphones and software in their villages. Thus, Ferreira Filho highlights how the choices made by the indigenous population are guided not only by practical skills, but also by political techniques. This combination allows a rereading of the notion of technical trend (Leroi-Gourhan, 1971), while showing how the study of the concatenation of operational sequences that give life to the technical process becomes more complex.

Júlia Brussi likewise contributes to the debate on the operational sequence, recalling that actions have different levels (Roux \& Bril, 2002), thereby underlining the gestures and rhythms that express operational behaviour (Leroi-Gourhan, 1993; Bidet, 2007). The article describes and analyses how women in a settlement on the Northeast coast of Brazil (in the state of Ceará) produce bobbin-lacing in domestic spaces. The action of knocking the wooden bobbins produces a characteristic sound, which is associated with the rhythm responsible for generating tension and thus stabilizing the beautiful forms produced by the lines.

The hospital environment also brings a series of techniques involving sophisticated manual abilities, such as those involved in heart surgery studied by Marini. Interested especially in problematizing the distinction between the functional and the symbolic in the institution of the surgical field, she employs the notion of actant (Latour, 1994) to demonstrate how the desired procedures of depersonalization, or the subject's erasure, are activated in the flux of the surgeon's activities.

Finally, the skilled relation with objects and their potential for mediation are explored through images. In a photographic essay, Pires investigates the different uses of the lasso in cattle breeding through an ethnography based in the floodland regions close to the Amazon estuary. Through this thought-provoking association between photography - one of the methodologies most used in this field of studies ${ }^{5}$ and rope perhaps the most malleable and versatile of tools - we invite the reader to get to know better, through these articles, the plurality of concepts, methods and themes of the contemporary Brazilian production on the anthropology of technique.

Received: September 6, 2019

Accepted: October 10, 2019

Translation by David Rodgers

\footnotetext{
5 We can also note the intense use of audiovisual records of technical processes (Sautchuk, 2012), resulting in the production of films, something also present among researchers from other countries (e.g. Buob, 2016). The research project Transformações técnicas (Technical transformations) resulted in a video of the same name (https://vimeo.com/canaliris/transformacoestecnicas) and we can cite also other ethnographic films like Sangria (https://vimeo. com/canaliris/sangria), A Cobra (https://vimeo.com/canaliris/acobra), Outro Fogo (https://vimeo.com/canaliris/outrofogo) and Ver Peixe (https://vimeo. $\operatorname{com} / 252378822)$.
} 


\section{Bibliograph}

ANDERSON, David G.; LOOVERS, Jan Peter Laurens; SCHROER, Sara Asu; WISHART, Robert P. 2017.

"Architectures of Domestication: On Emplacing Human-Animal Relations in the North: Architectures of Domestication". Journal of the Royal Anthropological Institute, 23(2): 398-416.

APPADURAI, A (ed.). 1986. The Social Life of Things: Commodities in Cultural Perspective. Cambridge:

Cambridge University Press.

AKRICH, Madeleine. 1989. "La construction d'un système socio-technique: esquisse pour une anthropologie des techniques". Anthropologie et Societés, 13(2): 31-54.

. 1992. "The de-scription of technical objects". In: W. Bijker; J. Law (eds.), Shaping Technology/Building

Society: Studies in Sociotechnical Change. Cambridge, MA: MIT Press. pp. 205-224.

BRIL, Blandine. 1991. “Techniques du Corps”. In: P. Bonte; M. Izard (eds.), Dictionnaire de l'Ethnologie et de

l'Anthropologie. Paris: PUF.

BARTH, Fredrik. 1992. "Towards greater naturalism in conceptualizing societies”. In: A. Kuper (ed.),

Conceptualizing society. London and New York: Routledge. pp. 17-33

BIDET, Alexandra. 2007. “Le Corps, le rythme et l'esthetique sociale chez André Leroi-Gourhan”. Tecniques \& Culture, 48-49(1-2): 15-38.

BRAY, Francesca. 2007. "Gender and Technology". Annual Review of Anthropology, 36: 37-53.

BUOB, Baptiste. 2016. "Ce que la caméra peut faire (dire) aux techniques: la médiation cinémato-graphique et le destinataire (trouble) du geste" Images du travail, travail des images, 3.

BUOB, Baptiste; CHEVALLIER, Denis; GOSSELAIN, Olivier. 2019. «Technographies».

Techniques \& Culture, 71: 10-25.

CAMBIANO, Giuseppe. 1971. Platone e le tecniche. Torino: Einaudi

CANGUILHEM, Georges. 1991. The Normal and the Pathological. New York: Zone Books. . 2008. Knowledge of Life. New York: Fordham University Press.

CHUA, L.; SALMOND, A. 2012. "Artefacts in anthropology". In: The SAGE Handbook of Social Anthropology, vol. 2. Portland: Ringgold. pp. 101-114.

COUPAYE, Ludovic. 2009. "What's the Matter with Technology? Long (and Short) Yams, Materialisation and Technology in Nyamikum Village, Maprik District, Papua New Guinea". The Australian Journal of Anthropology, 20(1): 93-111.

. 2013. Growing Art, Displaying Relationships: Yams, Art and Technology amongst the Nyamikum Abelam of Papua New Guinea. New York: Berghahn Books.

. 2017. "Cadeia Operatória, Transectos e Teorias: Algumas Reflexões e Sugestões Sobre o Percurso de

Um Método Clássico". In: C. E. Sautchuk (ed.), Técnica e Transformação: perspectivas antropológicas. Rio de Janeiro: ABA Publicações. pp. 475-94.

COUPAYE, Ludovic; DOUNY, Laurence. 2009. "Dans la Trajectoire des Choses: Comparaison des approches francophones et anglophones contemporaines en anthropologie des techniques”. Techniques \& Culture, 52-53:12-39.

COUPAYE, Ludovic; PITROU, Perig. 2018. "Introduction. The Interweaving of Vital and Technical Processes in Oceania". Oceania, 88(1): 2-12.

CRESSWELL, Robert. 1991. “Technologie”. In: P. Bonte; M. Izard (orgs.), Dictionnaire de l'ethnologie et de l'anthropologie. Paris: PUF. pp. 698-701.

DESCOLA, P. 2013. Beyond Nature and Culture. Chicago: University of Chicago Press.

ELIAS, Norbert. 1978. What is Sociology? London/ New York: Hutchinson \& Columbia University Press. 
FERRET, Carole. 2014. "Towards an anthropology of action: From pastoral techniques to modes of action". Journal of Material Culture, 19(3): 279-302.

FOUCAULT, Michel. 1975. Surveiller et punir. Naissance de la prison. Paris: Gallimard.

. 1994. "Omnes et singulatim: vers une critique de la raison politique". In: Dits et Écrits 1954-1988, vol. IV (1980-1988). Paris: Gallimard. pp. 134-161.

GELL, A. 1998. Art and Agency: An Anthropological Theory. Oxford: Clarendon Press.

GUCHET, Xavier. 2017. 'Objet versus Artefact. Pour une philosophie des techniques orientée-objet'. Cahiers COSTECH 1.

GUILLE-ESCURET, Georges. 1989. Les Sociétés et Leurs Natures. Paris: Armand Colin.

HAUDRICOURT, André-Georges. 1969. "Domestication of Animals, Cultivation of Plants and Human Relations". Social Science Information, 8(3):163-72.

. 1987. La Technologie, Science Humaine: Recherches d'histoire et d'ethnologie Des Techniques. Paris:

Editions de la Maison des Sciences de l'Homme. . 2010. Des Gestes Aux Techniques: Essai Sur Les Techniques Dans Les Sociétés Pré-Machinistes. Paris :

Maison des Sciences de l'Homme.

HICKS, Dan. 2010. 'The Material Cultural Turn: Event and Effect'. In: The Oxford Handbook of Material Culture Studies. Oxford: Oxford University Press. pp. 25-98.

HORNBORG, Alf. 2014. "Technology as Fetish: Marx, Latour, and the Cultural Foundations of Capitalism". Theory, Culture \& Society, 31(4): 119-40. . 2017. Global Magic: Technologies of Appropriation from Ancient Rome to Wall Street. New York: Palgrave.

HUTCHINS, Edwin. 2001. “Cognition, distributed”. In: N. Smelser; P. Baltes (eds.), International encyclopedia of the social \& behavioral science. Amsterdam/ New York: Elsevier. pp. 2068-2072.

INGOLD, Tim. 1980. Hunters, Pastoralists and Ranchers: Reindeer Economies and Their Transformations.

Cambridge: Cambridge University Press. . 1997. "Eight Themes in the Anthropology of Technology". Social Analysis, 41(1): 106-38. . 1999. "'Tools for the hand, language for the face': An appreciation of Leroi-Gourhan's gesture and speech". Studies in History and Philosophy of Science, 30(4): 411-453. . 2000. The Perception of the Environment: essays on livelihood, dwelling and skill. Londres: Routledge. . 2011. Being Alive. Essays on movement, knowledge and description. New York/London: Routledge. 2013. Making. Anthropology, archaeology, art and architecture. New York/London: Routledge. . 2014. "Resonators uncased: Mundane objects or bundles of affect?" Hau, 4(1): 517-521.

KARSENTI, Bruno. 1998. “Techniques Du Corps et Normes Sociales: De Mauss à Leroi-Gourhan”. Intellectica, $1(2): 227-39$.

LATOUR, Bruno. 1996. Aramis, or, The Love of Technology. Cambridge, Mass: Harvard University Press. . 1992. "Where are the missing masses, sociology of a few mundane artefacts". In: W. Bijker; J. Law (eds.), Shaping Technology-Building Society: Studies in Sociotechnical Change. Cambridge, MA: MIT Press. pp. 225-259. . 1994. "On technical Mediation - Philosophy, Sociology, Genealogy". Common Knowledge, 3(2): 29-64. . 2010. "Prendre le pli des techniques". Réseaux, 5(163): 15-31. . 2013. An Inquiry into Modes of Existence: An Anthropology of the Moderns. Cambridge, Massachusetts: Harvard University Press. . 2014. "Technical does not mean material". Hau, 4(1): 507-510.

LATOUR, Bruno; LEMONNIER, Pierre (eds.). 1994. De La Préhistoire Aux Missiles Balistiques: L'intelligence Sociale Des Techniques. Paris: La Découverte. 
. 1994. "Introduction: Genèse Sociale des Techniques, Genèse Technique Des Humains". In: B. Latour; P. Lemonnier (orgs.), De la préhistoire aux missiles balistiques: l'intelligence sociale des techniques. Paris:

La Découverte. pp. 9-24.

LEMONNIER, Pierre. 1991. “Technique (Système)”. In: P. Bonte; M. Izard (orgs.), Dictionnaire de l'ethnologie et de l'anthropologie. Paris: PUF. pp. 697-98.

. 1992. Elements for an anthropology of technology. Ann Arbor, Mich: Museum of Anthropology,

University of Michigan.

. (org.). 1993. Technological Choices: Transformation in Material Cultures since the Neolithic. 1a edição.

London: Routledge.

. 2011. “Technology”. In: Nick Thieberger (ed.), The Oxford Handbook of Linguistic Fieldwork. Oxford:

Oxford University Press. pp. 298-316.

. 2012. Mundane Objects: Materiality and Non-Verbal Communication. London: Routledge.

LEROI-GOURHAN, André. 1971. Évolution et techniques I - L’Homme et la Matière. Paris: Albin Michel. . 1993. Gesture and Speech. Cambridge, Mass: MIT Press.

MARX, Leo. 1997. “Technology”: The Emergence of a Hazardous Concept”. Social Research, 64(3): 965-88.

MAUSS, Marcel. 2006a. Techniques, Technology and Civilisation. New York: Durkheim Press/Berghahn Books. . 2006b. "Techniques of the Body". Techniques, Technology and Civilisation. New York: Durkheim Press/ Berghahn Books. pp. 77-96.

MALINOWSKI, Bronislaw. 1984. Argonauts of the Western Pacific. Prospect Heights: Waveland Press.

MASSUMI, Brian. 2014. What Animals Teach us about Politics. Durham: Duke University Press.

MILLER, D. 2005. “Materiality: an Introduction”. In: D. Miller (ed.), Materiality. Durham, NC: Duke University Press. pp. 1-50.

MURA, Fabio. 2000. Habitações Kaiowa: forma, propriedades técnicas e organização social. Dissertação de mestrado. PPGAS-MUSEU NACIONAL/Universidade Federal do Rio de Janeiro.

. 2011. "De sujeitos e objetos: um ensaio crítico de Antropologia da técnica e da tecnologia".

Horizontes Antropológicos, 17(36): 95-125.

. 2017. "A política como técnica de uso e como ato transformador: algumas reflexões a partir do caso dos Kaiowa de Mato Grosso do Sul". In: Carlos Sautchuk (org.), Técnica e transformação: perspectivas antropológicas. Rio de Janeiro: ABA Publicações. pp. 37-66.

. 2019. À procura do "bom viver": Território, tradição de conhecimento e ecologia doméstica entre os Kaiowa.

Rio de Janeiro: ABA Publicações.

NUGENT, Stephen. 2018. The Rise and Fall of the Amazon Rubber Industry: An Historical Anthropological Account. Abingdon, Oxon; New York/ New York: Routledge.

PEIRANO, Mariza. 1991. "The anthropology of anthropology: The Brazilian case”. Série Antropologia, 110. Departamento de Antropologia, Universidade de Brasília.

. 1999. "Antropologia no Brasil (alteridade contextualizada)". In: Sergio Miceli (org.), O que ler na ciência social brasileira (1970-1995). São Paulo: Sumaré/ Anpocs. pp. 225-266.

PFAFFENBERGER, Bryan. 1988. "Fetishised Objects and Humanised Nature: Towards an Anthropology of Technology". Man, 23(2): 236 . . 1992. "Social Anthropology of Technology". Annual Review of Anthropology, 21(1): 491-516.

PITROU, P. 2015. "Life as a process of making in the Mixe Highlands (Oaxaca, Mexico): Towards a general pragmatics' of life”. Journal of the Royal Anthropological Institute, 21: 86-105. 
ROUX, Valentine; BRIL, Blandine. 2002. "Observation et Experimentation de Terrain: Des Collaborations Fructueuses pour l'Analyse de l'Expertise Technique. Le Cas de la Taille de Pierre en Inde”. In: V. Roux; B. Bril (eds.), Le Geste Technique: Réflexions Méthodologiques et Anthropologiques. Ramonville Saint-Agne: Editions Erès. pp. $29-48$.

SAUTCHUK Carlos Emanuel. 2005. "Laguistas et pescadores. L'apprentissage de la pêche dans une région côtière de l’Amazonie (Vila Sucuriju, Brésil)". Techniques \& Culture, 45:161-186. . 2010. "Ciência e Técnica". In: C. B. Martins; L. F. D. Duarte (orgs.), Horizontes das Ciências Sociais no Brasil - Antropologia. São Paulo: ANPOCS. pp. 97-122 . 2012. "Cine-Weapon: The Poiesis of Filming and Fishing". Vibrant, 9(2): 406-30. . 2015. "Aprendizagem como gênese: prática, skill e individuação". Horizontes Antropológicos, 21(44): 109-39. . (ed.). 2017. Técnica e Transformação: perspectivas antropológicas. Rio de Janeiro: ABA Publicações. 2019. "The Pirarucu Net: Artefact, Animism and the Technical Object". Journal of Material Culture, $24(2): 176-93$. . Forthcoming. $O$ arpão e o anzol: técnica e pessoa na Amazônia. Brasília: Editora UnB.

SCHATZBERG, Eric. 2018. Technology: Critical History of a Concept. Chicago; London: The University of Chicago Press.

SCHIFFER, Michael. 2001. “Toward an Anthropology of Technology”. In: M. Schiffer (org.), Anthropological Perspectives on Technology. Albuquerque: University of New Mexico Press. pp. 1-15.

SCHLANGER, Nathan. forthcoming. André Leroi-Gourhan on Technology, Evolution, and Social Life: A Selection of Texts and Writings from the 1930s to The 1970s. Chicago: The University of Chicago Press.

SÉRIS, Jean-Pierre. 1994. La Technique. Paris: PUF.

SIGAUT, François. 1994. “Technology”. In: T. Ingold (org.), Companion encyclopedia of anthropology. London: Routledge. pp. 420-59. 2012. Comment Homo devint faber comment l'outil fit l'homme. Paris: CNRS Éditions.

SILVA, Fabíola. 2002. "As Tecnologias e Seus Significados". Canindé - Revista do Museu de Arqueologia de Xingó, 2: 119-38.

SIMIÃO, Daniel; FELDMAN-BIANCO, Bela. 2018. O campo da antropologia no Brasil: retrospectiva, alcances e desafios. Rio de Janeiro: Associação Brasileira de Antropologia.

SIMONDON, G. 2005. L'individuation à la lumière des notions de forme et d'information. Grenoble: Millon. . 2016. On the Mode of Existence of Technical Objects. Minneapolis, MN: Univocal Pub.

STEWARD, Julian. 1955. Theory of culture change. Urbana: Univ. of Illinois Press.

SWARTZ, Marc; TURNER, J.; VICTOR, W.; TUDEN, A. 1966. “Introduction”. In: (eds.), Political Anthropology. Chicago: Aldine. pp. 1-42.

UEXKULL, Jacob von. 2010 (1934). A foray into the worlds of animals and humans (with A Theory of Meaning). Minneapolis, London: University of Minnesota Press.

WHITE, Leslie. 1949. "Energy and the evolution of culture". In The science of culture: a study of man and civilization. New York: Grove Press. pp. 363-396. 


\section{Fabio Mura}

Laboratory of Studies in Technical Processes, Department of Social Science,

Federal University of Paraiba

https://orcid.org/0000-0003-2840-6355

Author's email: fabiomura64@gmail.com

Carlos Emanuel Sautchuk

Laboratory of Anthropology of Science and Technique, Department of Anthropology,

University of Brasilia

https://orcid.org/oooo-0002-2427-2153

Author's email: cemanuel@unb.br 